\title{
PROSPEK PENEMPATAN PERJANJIAN INTERNASIONAL YANG MENGIKAT INDONESIA DALAM HIERARKI PERATURAN PERUNDANG- UNDANGAN INDONESIA*
}

\author{
Aminoto** $^{* a n}$ Agustina Merdekawati*** \\ Bagian Hukum Tata Negara dan Bagian Hukum Internasional \\ Fakultas Hukum Universitas Gadjah Mada, Yogyakarta \\ Jalan Sosio Yustisia Nomor 1, Bulaksumur, Sleman, D.I. Yogyakarta 55281
}

\begin{abstract}
This research aims to know understand the prospects to include international treaties binding to Indonesia in the hierarchy of Indonesian statutory regulations, from the aspects of urgency and challenges. This research is a legal research. Therefore, the data collecting method applied for this research mainly focuses on literature reseach. These materials will be analyzed with a statutory, and comparative approach. The analysis of this research concluded that: Firstly, there were seven reasons of urgency to place international treaties in the hierarchy of statutory regulations and Secondly, there were four main challenges to place international treaties in the hierarchy of statutory regulations.
\end{abstract}

Keywords: international treaties, hierarchy of statutory regulations.

\section{Intisari}

Penelitian ini bertujuan untuk mengetahui peluang penempatan perjanjian internasional yang mengikat Indonesia dalam hierarki peraturan perundang-undangan yang terdiri dari aspek urgensi dan tantangan. Penelitian ini merupakan penelitian yuridis. Pengumpulan sumber-sumber penelitian menggunakan penelitian kepustakaan (literature reseach) dengan metode pendekatan peraturan perundang-undangan dan pendekatan perbandingan. Hasil penelitian ini menunjukkan bahwa: Pertama, ada tujuh alasan utama urgensi penempatan perjanjian internasional dalam hierarki Peraturan Perundang-undangan Indonesia; dan Kedua, ada empat tantangan dalam penempatan perjanjian internasional dalam hierarki peraturan perundang-undangan Indonesia.

Kata Kunci: perjanjian internasional, hierarkhi, peraturan perundang-undangan.

\section{Pokok Muatan}

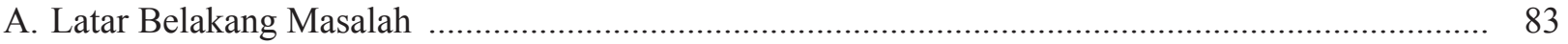

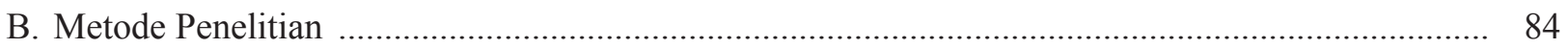

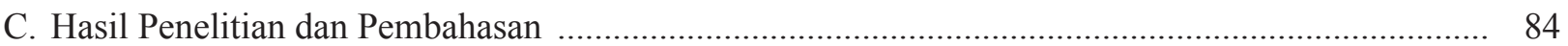

1. Urgensi Penempatan Perjanjian Internasional yang Mengikat Indonesia dalam Hierarki Peraturan Perundang-Undangan

2. Tantangan Penempatan Perjanjian Internasional yang Mengikat Indonesia dalam Hierarki Peraturan Perundang-Undangan 92

D. Kesimpulan 95

Hasil Penelitian Kelompok dari Unit Penelitian dan Pengabdian Kepada Masyarakat (P2M) Fakultas Hukum UGM.

Alamat korespondensi: aminoto@ugm.ac.id

*** Alamat korespondensi: agustina_merdekawati@ugm.ac.id 


\section{A. Latar Belakang Masalah}

Penempatan perjanjian internasional (PI) yang telah diratifikasi/diaksesi oleh Pemerintah Indonesia dalam bentuk Undang-Undang (UU) maupun Peraturan Presiden adalah praktek yang telah berlangsung lama dan konsisten hingga saat ini, meskipun Pemerintah Indonesia telah berganti era mulai dari era orde lama hingga pasca reformasi, mulai dari rezim Surat Presiden Nomor 2826/ HK/1960 hingga rezim UU No. 24 Tahun 2000 tentang Perjanjian Internasional. Praktek tersebut juga konsisten berkontribusi dalam menciptakan ketidakjelasan kedudukan perjanjian internasional yang telah diratifikasi/diaksesi oleh Pemerintah Indonesia dalam Sistem Hukum Nasional Indonesia.

Salah satu konsekuensi atas ketidakjelasan kedudukan terlihat pada terhambatnya proses pemenuhan perjanjian internasional yang telah diratifikasi/diaksesi oleh Pemerintah Indonesia.

Ketidakjelasan tersebut dapat dilihat dari status perjanjian internasional pasca perjanjian internasional tersebut diratifikasi atau diaksesi oleh Pemerintah Indonesia. Apakah bentuk peratifikasian, yang menempatkan perjanjian internasional dalam lampiran undang-undang tersebut membuat perjanjian internasional terlampir menjadi hukum positif yang berlaku di Indonesia atau tidak? pertanyaan ini merespon berbagai praktek yang belum menunjukkan adanya keseragaman pendapat di Indonesia. Paling tidak, terdapat 2 (dua) pendapat yang berbeda yang masing-masing didukung dengan argumen hukum dan merujuk pada praktik yang berlaku di Indonesia. Pertama, mengatakan produk hukum pengesahan perjanjian internasional sebagai produk yang menjadikan norma-norma hukum dalam perjanjian internasional tersebut menjadi bagian dari hukum nasional Indonesia. Hal ini berarti pasca diratifikasi/diaksesinya suatu perjanjian internasional maka secara otomatis sejak saat diundangkannya produk hukum pengesahan tersebut seluruh ketentuan perjanjian tersebut dapat langsung diterapkan di Indonesia. Kedua, menyatakan bahwa norma-norma hukum internasional hanya dapat berlaku dan diterapkan di pengadilan nasional setelah melalui proses transformasi, yang mana substansi perjanjian internasional harus dijabarkan ke dalam peraturan hukum nasional Indonesia. Hal ini berarti bahwa dilampirkannya perjanjian internasional dalam UU ratifikasi hanya dimaksudkan sebagai pengakuan atas authetifikasi perjanjian internasional terlampir sebagai perjanjian otentik yang diratifikasi.

Ketidakjelasan posisi perjanjian internasional dalam tataran implementasi di hukum nasional tersebut juga didukung oleh kondisi adanya penyempitan makna hukum positif di Indonesia, dimana kecenderungan yang terjadi di Indonesia saat ini, bahwa hukum positif di Indonesia identik dengan apa yang diatur secara tegas dalam UndangUndang Republik Indonesia Nomor 12 Tahun 2011 tentang Pembentukan Peraturan PerundangUndangan. Hal ini berdampak bahwa bentuk-bentuk hukum positif lain yang secara material merupakan sumber hukum (sumber hukum material) tidak dipergunakan dalam praktek. Salah satunya adalah perjanjian internasional. Persoalan lain yang muncul adalah terkait dengan status perjanjian internasional yang dibungkus dalam bentuk formal UU yakni terbukanya peluang bagi Mahkamah Konstitusi untuk melakukan review terhadap Undang-Undang Ratifikasi (UUR) tersebut termasuk terhadap klausula-klausula yang diatur dalam naskah perjanjian internasional yang terlampir UUR secara internal tanpa meminta persetujuan dari negara pihak yang lain. Fakta ini jelas akan sangat bertentangan dengan ketentuan yang diatur dalam hukum internasional khususnya Pasal 26, Pasal 27, dan Pasal 46 Konvensi Wina 1969.

Kedua persoalan tadi perlu mendapat perhatian yang cukup serius, karena membiarkan kondisi tersebut tetap berlangsung tentu tidak akan menguntungkan bagi posisi Indonesia dalam hubungan internasional. Hal ini karena akan membangun image bahwa Pemerintah Indonesia kurang serius dalam pemenuhan kewajiban yang lahir sebagai konsekuensi keterikatan Indonesia atas 
perjanjian internasional. Pertanyaan selanjutnya, mengapa praktik yang tidak menguntungkan ini terus dipertahankan dari masa ke masa, apakah ini adalah sebuah amanat konstitusi yang harus dilakukan, ataukah ini hanya pilihan kebijakan yang dianggap paling sesuai di era dulu namun perlu dikaji kembali untuk diterapkan saat ini.

Berdasarkan pada latar belakang tersebut maka, peneliti tertarik untuk melakukan pengkajian/penelitian lebih lanjut, dengan rumusan permasalahan sebagai berikut: Pertama, bagaimana urgensi penempatan perjanjian internasional yang mengikat Indonesia dalam hierarki peraturan perundang-undangan?; dan Kedua, bagaimana tantangan penempatan perjanjian internasional yang mengikat Indonesia dalam hierarki peraturan perundang-undangan?

\section{B. Metode Penelitian}

Penelitian ini berdasarkan bidangnya termasuk dalam kategori penelitian hukum, sementara berdasarkan pada tujuan essensialnya, penelitian ini merupakan penelitian terapan (applied research). Untuk memecahkan isu hukum dan sekaligus memberikan preskripsi mengenai apa yang seyogyanya maka dalam penelitian ini diperlukan sumber-sumber penelitian yang berupa:

1. Bahan hukum primer yang mengacu pada ketentuan-ketentuan peraturan perundangundangan sebagaimana yang diatur dalam Pasal 7 Undang-Undang Nomor 12 Tahun 2011 tentang Pembentukan Peraturan Perundang-undangan dan ketentuan yang diatur dalam Pasal 38 (1) Statuta Mahkamah Internasional.

2. Bahan hukum sekunder adalah bahan hukum yang memberikan penjelasan mengenai bahan hukum primer.

3. Bahan-bahan non hukum adalah bahan di luar bidang hukum atau berasal dari disiplin ilmu lain yang berguna untuk memperluas dan memperkaya wawasan peneliti dalam memahami persoalan hukum yang ada, sepanjang relevan dengan bidang penelitian.

Untuk kepentingan analisis atas hasil penelitian, metode pendekatan digunakan dalam menganalisis hasil adalah:

1. Pendekatan undang-undang (statutory approach) yakni dengan melakukan kajian terhadap ketentuan perundangan yang relevan dengan tema penelitian.

2. Pendekatan perbandingan (comparative approach) yakni dengan membandingkan undang-undang (hukum) dalam satu negara dengan undang-undang (hukum) pada satu atau beberapa negara yang lain mengenai hal yang sama.

\section{Hasil Penelitian dan Pembahasan}

Penempatan perjanjian internasional yang telah diratifikasi/diaksesi oleh Pemerintah Indonesia dalam bentuk Undang-Undang maupun Peraturan Presiden menciptakan ketidakjelasan kedudukan perjanjian internasional yang telah diratifikasi/ diaksesi oleh Pemerintah Indonesia dalam sistem hukum nasional. Sebagai implikasinya adalah terhambatnya proses pemenuhan pemenuhan perjanjian internasional yang telah diratifikasi/ diaksesi oleh Pemerintah Indonesia tersebut. Praktik yang tidak menguntungkan ini, tidak seharusnya terus dipertahankan dari masa ke masa. Hal ini mengingat bahwa praktek ini bukanlah sebuah amanat konstitusi yang harus dilakukan ${ }^{1}$, namun lebih pada persoalan pilihan kebijakan yang dianggap paling sesuai di era dulu namun perlu direview kembali untuk diterapkan saat ini.

Satu-satunya ketentuan hukum yang menegaskan keharusan menempatkan perjanjian internasional yang sudah diratifikasi/aksesi oleh Pemerintah Indonesia dalam bentuk Undang-undang adalah dalam Pasal 9 (2) UU No. 24 Tahun 2000 yang mengatakan bahwa "Pengesahan perjanjian 
internasional sebagaimana dimaksud dalam ayat (1) dilakukan dengan undang-undang atau keputusan Presiden. Keberadaan pasal tersebut jelas bukan amanat langsung dari konstitusi namun menjadi wajar karena memotret praktik yang puluhan tahun berlangsung di Indonesia sejak berlakunya Surat Presiden Nomor 2826/HK/1960. Ketentuan tersebut juga dikuatkan dengan ketentuan dalam sistem hierarki peraturan perundang-undangan di Indonesia yang telah diubah selama $4 \mathrm{kali}^{2}$, juga tidak memberikan tempat tersendiri untuk perjanjian internasional.

Kondisi ini berbeda dengan ketentuan ini berbeda dengan beberapa negara lain yang memberikan tempat yang jelas bagi perjanjian internasional dalam hierarki sistem perundangundangannya. Di Amerika serikat sebagai contohnya bahwa perjanjian internasional (Federal Treaties) akan ditempatkan sejajar dengan Federal Statutes ${ }^{3}$ dan Supreme Court Rules. ${ }^{4}$ Demikian pula di Korea Selatan bahwa treaties and international law akan disejajarkan dengan Act dan Emergency Executive Orders, Emergency Financial and Economic Executive Orders. ${ }^{5}$ Demikian pula dalam hierarki peraturan perundang-undangan di Uni Eropa Treaty mendapat tempat tersendiri sebagai Primary Law yakni sumber hukum tertinggi setelah Konstitusi Uni Eropa. ${ }^{6}$ Pemberian tempat tersendiri bagi perjanjian internasional dalam sistem hukum nasional di beberapa negara tersebut cukup efektif dalam menentukan status perjanjian internasional dalam sistem hukum nasional Indonesia.

\section{Urgensi Penempatan Perjanjian Interna- sional yang Mengikat Indonesia dalam Hierarki Peraturan Perundang-Unda- ngan.}

\section{a. Adanya Pergeseran Paradigma Pemak- naan Sumber Hukum}

Lampiran 1 Undang-Undang Republik Indonesia Nomor 12 Tahun 2011 tentang Pembentukan Peraturan Perundang-undangan menyatakan, bahwa sistem hukum nasional yakni hukum yang berlaku di Indonesia dengan semua elemennya yang saling menunjang satu dengan yang lain dalam rangka mengantisipasi dan mengatasi permasalahan yang timbul dalam kehidupan bermasyarakat, berbangsa, dan bernegara yang berdasarkan Pancasila dan Undang-Undang Dasar Negara Republik Indonesia Tahun 1945. ${ }^{7}$ Sebagai konsekuensinya maka seluruh aparatur/pejabat negara maupun masyarakat Indonesia sudah seharusnya untuk memandang hukum dalam perspektif yang sangat luas dan yang terepresentasikan dalam berbagai bentuk.

Kecenderungan yang terjadi saat ini bahwa dominasi aliran legisme (positivisme) menjadi begitu besar sehingga melahirkan hukum dalam sketsa matematika, menyelesaikan hukum yang terjadi dalam masyarakat hanya berdasarkan apa yang tertulis dalam teks semata. ${ }^{8}$ Kecenderungan ini dapat dengan mudah diamati dalam praktek dimana eksistensi hukum-hukum tidak tertulis kemudian mulai menghilang secara perlahan-lahan. Dalam mengadili suatu kasus misalnya hakim-hakim

Mulai dari ketentuan dalam Majelis Permusyawaratan Rakyat Sementara Republik Indonesia Nomor XX/MPRS/1966 Tahun 1966 tentang Memorandum DPR-GR Mengenai Sumber Tertib Hukum Republik Indonesia dan Tata Urutan Peraturan Perundangan Republik Indonesia, Ketetapan Majelis Permusyawaratan Rakyat Republik Indonesia Nomor III/MPR/2000 tentang Sumber Hukum dan Tata Urutan Peraturan Perundang-Undangan, Undang Undang Republik Indonesia Nomor 10 Tahun 2004 tentang Pembentukan Peraturan Perundang Undangan, dan terakhir dengan Undang-Undang Republik Indonesia Nomor 12 Tahun 2011 tentang Pembentukan Peraturan Perundang-Undangan.

Federal Statutes merupakan produk bersama lembaga legislatif dengan lembaga eksekutif di Amerika Serikat. Nama lainnya adalah Act of the Congress.

Federal Court Rules adalah segala bentuk Putusan Pengadilan Mahkamah Agung Amerika Serikat (Supreme Court).

Merupakan peraturan yang dikeluarkan oleh Presiden dalam hal terjadi keadaan darurat nasional dan akan memiliki kekuatan seperti undangundang hanya apabila Presiden memperoleh persetujuan dari Majelis Nasional.

Herwig Hoffman, 2012, Hierarchy of Norms in European Union Law (after The Lisbon Treaty), University of Luxembourg, Luxembourg, hlm. 2 .

Lihat Lampiran 1 Undang-Undang Republik Indonesia Nomor 12 Tahun 2011 tentang Pembentukan Peraturan Perundang-undangan (Tambahan Lembaran Negara Republik Indonesia Nomor 5234).

Lintong O. Siahaan. "Peran Hakim dalam Pembaharuan Hukum di Indonesia", Jurnal Hukum dan Pembangunan, Vol. 36, No. 1, Januari 2006, hlm. 35 . 
sesuai dengan Pasal 5 ayat (1) UU No. 48 Tahun 2009 tentang Pokok-Pokok Kekuasaan Kehakiman seharusnya menggali, mengikuti, dan memahami nilai-nilai hukum dan rasa keadilan yang hidup dalam masayarakat, bukan sekedar mengutamakan hukum tertulis semata.

Di Indonesia, dominasi aliran legisme (positivisme) bahkan terlihat tidak hanya sebatas penyesampingan hukum tidak tertulis saja (kebiasaan/custom), namun sudah mengarah pada penyempitan paradigma tentang hukum positip yang ada sebatas hukum yang diatur dalam hierarkhi peraturan perundang-undangan yang saat ini diatur dalam Pasal 7 dan 8 Undang-Undang Republik Indonesia Nomor 12 Tahun 2011 tentang Pembentukan Peraturan Perundang-undangan. Norma-norma lain selain yang diatur dalam Pasal 7 dan 8 tersebut menjadi terabaikan sehingga sering dipertanyakan eksistensinya.

Persepsi ini sebenarnya bertentangan dengan hakikat pembentukan hierarki peraturan perundangundangan. Hal ini mengingat hierarki pada prinsipnya merupakan hubungan super dan subordinasi dalam konseks spasial antar norma hukum. Hubungan ini bukan hubungan tanpa aturan, namun menghendaki tata aturan yang baik karena akan memiliki konsekuensi hukum juga. Maka sebuah hirakhi hukum dalam sebuah negara harusnya dimaknai sebagai satu konsep hubungan super dan sub-ordinasi bukan sebagai bentuk "deklarasi" mengenai hukum positif yang berlaku dalam suatu negara. Namun pengaruh kuat dari aliran legisme ini telah mengubah pandangan sistem hierarki dari sebuah sistem tertib hukum menjadi sumber hukum positip negara. Maka wajar jika dalam praktek para hakim ataupun aparatur penegak hukum kemudian hanya berkaca pada peraturan-peraturan yang tertera dalam hierarki peraturan perundang-undangan.

Terkait dengan objek dalam penelitian ini yakni perjanjian internasional, sepertinya juga mengalami nasib yang sama dengan sumber hukum lain yang tidak tercantum dalam hierarki peraturan perundang-undangan di Indonesia. Dalam praktek jelas terlihat bahwa perjanjian internasional yang sudah diratifikasi/diaksesi oleh pemerintah Indonesia kurang mendapat tempat dalam hukum nasional Indonesia. Praktek tersebut misalnya:

1) Proses peradilan, Undang-Undang Ratifikasi Perjanjian Internasional yang digunakan baik oleh Terdakwa/Penasehat Hukum, Jaksa Penuntut Umum, Tergugat, Penggugat maupun saksi ahli hanya sedikit yang efektif, sebagian besar tidak digunakan oleh hakim.

2) Proses pembuatan undang-undang di Indonesia terlihat bahwa terdapat banyak konvensi Internasional yang telah diratifikasi namun tidak digunakan sebagai dasar menimbang/mengingat dalam undangundang tersebut.

3) Proses harmonisasi peraturan perundangundangan di Indonesia terlihat bahwa masih banyak terdapat konvensi internasional yang sudah diratifikasi namun belum diharmonisasikan dalam hukum nasional Indonesia.

Maka sebagai alternatif solusi untuk memastikan perjanjian internasional tetap mendapat tempat dalam sistem hukum nasional dan dominannya paham positivisme yang ada di Indonesia akan lebih baik jika Pemerintah Indonesia juga mengambil langkah penyesuaian dengan cara memasukkan perjanjian internasional yang sudah diratifikasi/dikasesi oleh Pemerintah Indonesia sebagai salah satu norma yang diatur dalam jenjang dan hierarki peraturan perundang-undangan di Indonesia. Praktek ini juga diperlakukan dibeberapa negara yang lain, misalnya Amerika Serikat dan Republik Korea sebagai berikut: 
Tabel 1.

Praktik Penempatan Perjanjian Internasional dalam Hukum Nasional

Amerika Serikat

\begin{tabular}{ccc}
\hline Level & Tier & Urutan Peraturan \\
\hline \multirow{4}{*}{ National Level } & I & United States Constitution \\
\cline { 2 - 3 } & II & $\begin{array}{c}\text { Federal Statues, Treaties, and Supreme } \\
\text { Court Rules }\end{array}$ \\
\cline { 2 - 3 } & III & Federal Adminitrative Agency Rules \\
\cline { 2 - 3 } & IV & Federal Common Law Caselaw \\
\hline \multirow{3}{*}{$\begin{array}{c}\text { Ltate Provincial } \\
\text { Level }\end{array}$} & VI & State Statutes, State/District Court Rules \\
\cline { 2 - 3 } & VII & State Administrative Agency Rules \\
\cline { 2 - 3 } & VIII & State Common Law Caselaw \\
\hline Other Sources & IX & Secondary Authorities \\
\hline
\end{tabular}

Sumber: Hierarchy of U.S. Law, 2014.

\section{b. Ketidakjelasan Pilihan Model Transfor-} masi Perjanjian Internasional

Ada 3 (tiga) pendekatan atau teori yang mencoba menjelaskan mekanisme adopsi (penerimaan) perjanjian internasional dalam sistem hukum nasional suatu negara. Ketiga pendekatan tersebut adalah: (1) inkorporasi (automatic standing incorporation); (2) legislative ad hoc incorporation (transformasi) baik (Statutory ad hoc incorporation of international rules maupun (automatic ad hoc incorporation of international law); dan (3) pragmatis. Mengacu pada perdebatan mengenai dua kubu aliran inkorporasi dan transformasi yang tidak berunjung, maka pilihan Indonesia untuk tidak mengikuti secara strict satu teori dan lebih memilih berada diantaranya (pragmatis) dinilai tepat oleh sebagaian kalangan. Maka, dalam praktek kemudian Indonesia membuat 3 (tiga) grade perjanjian internasional yakni:

1) Perjanjian Internasional yang akan dapat langsung berlaku tanpa mempersyaratkan adanya proses ratifikasi/aksesi. Terhadap perjanjian dalam kategori ini maka pilihan Indonesia adalah menerapkan teori Inkorporasi (automatic standing incorporation).

2) Perjanjian internasional yang memerlukan

\section{Korea Selatan}

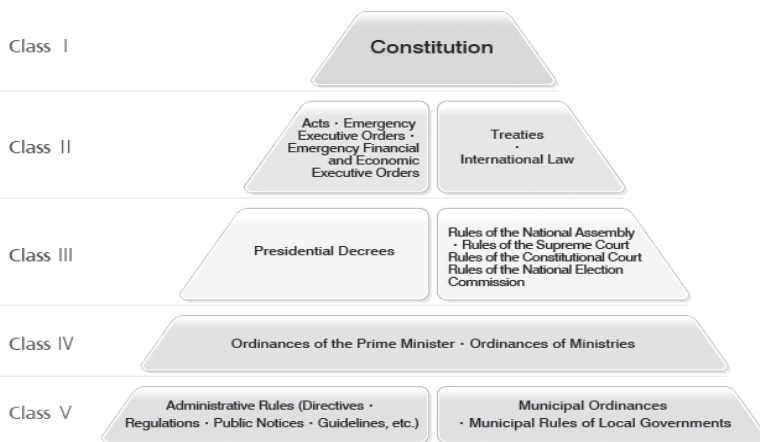

Sumber: Official Website Statutes of the Republic of Korea, 2014.

transformasi dalam hukum nasional (legislative ad hoc incorporation) dan memerlukan persetujuan Dewan Perwakilan Rakyat dalam proses tranformasinya. Wujud transformasinya adalah Undang-undang ratifikasi.

3) Perjanjian internasional yang memerlukan transformasi dalam hukum nasional (legislative ad hoc incorporation) namun tidak membutuhkan persetujuan Dewan Perwakilan Rakyat dalam proses tranformasinya. Wujud transformasinya adalah Peraturan Presiden.

Persoalan aplikasi substansi perjanjian internasional ke dalam hukum nasional yang sering muncul yakni pada kategori perjanjian internasional yang kedua dan ketiga ini. Sebagaimana kita ketahui dalam kedua kategori tersebut sebenarnya keduanya jelas menerapkan pandangan trasformasi. Hanya sayangnya dalam UU No. 24 Tahun 2000 tidak mengatur lebih detail mengenai pilihan transformasi yang diplih oleh Indonesia, apakah transformasi tersebut masuk dalam kategori Statutory ad hoc incorporation of international rules atau Automatic ad hoc incorporation of international law.

Ketidakjelasan pilihan model transformasi yang dipilih ini dalam praktek menimbulkan 
konsekuensi hukum yang sangat berbeda. Perbedaan penerapan kedua model tersebut adalah sebagai berikut:

1) Pandangan automatic ad hoc incorporation of international law akan menempatkan suatu produk hukum pengesahan perjanjian internasional adalah sebagai produk yang menjadikan norma-norma hukum dalam perjanjian internasional tersebut menjadi bagian dari hukum nasional Indonesia. Hal ini berarti bahwa pasca diundangkannya produk hukum pengesahan perjanjian internasional maka seluruh ketentuan perjanjian tersebut dapat langsung diterapkan di Indonesia. Pandangan ini cenderung menempatkan perjanjian internasional yang telah diratifikasi/diaksesi sebagai self-executing treaty.

2) Pandangan statutory ad hoc incorporation of international rules menyatakan bahwa norma-norma hukum internasional hanya dapat berlaku dan diterapkan di pengadilan nasional setelah melalui proses transformasi, yang mana substansi perjanjian internasional harus dijabarkan ke dalam peraturan hukum nasional Indonesia. Proses transformasi ke dalam bentuk Undang-Undang ini tidak harus dilakukan melalui sebuah Undang-Undang khusus (an exclusive act of parliament), melainkan juga dapat disisipkan ke dalam Undang-Undang nasional yang berkaitan dengan materi perjanjian dan/atau melalui amandemen Undang-Undang nasional yang telah berlaku. Pandangan ini berpendapat bahwa Undang-Undang pengesahan ini sama sekali tidak ada hubungannya dengan kewenangan DPR dalam hal pembuatan peraturan perundang-undangan seperti yang diatur dalam Pasal 20 UUD 1945. UndangUndang pengesahan tidak serta merta membuat suatu perjanjian internasional menjadi bagian hukum nasional Indonesia. Kalimat "Undang-Undang ini mulai berlaku sejak tanggal diundangkan" bukan dimaksudkan untuk menunjukkan bahwa perjanjian internasional tersebut berlaku di Indonesia sehingga seakan-akan pula sistem ketatanegaraan Indonesia mengakui perjanjian internasional tersebut, namun lebih ditujukan pada pemerintah sebagai legal basis untuk instrument of ratification, artinya setelah berlakunya Undang-Undang ini, maka Presiden menggunakannya sebagai dasar untuk meratifikasi perjanjian internasional secara eksternal. Tidak ada ketentuan hukum nasional yang menyatakan bahwa norma-norma hukum internasional yang terkandung dalam sebuah perjanjian internasional dan telah diratifikasi oleh Pemerintah Indonesia secara ipso facto berlaku dan dapat diterapkan di pengadilan nasional. ${ }^{9}$ Pandangan ini cenderung menempatkan perjanjian internasional yang telah diratifikasi/diaksesi sebagai non-selfexecuting treaty.

Implikasinya dalam praktek kemudian menimbulkan kebingungan bagaimana kekuatan hukum dari substasi yang diatur dalam perjanjian internasional sejak ada tindakan pengesahan tersebut, apakah sudah menjadi ketentuan hukum yang berlaku mengikat atau belum. Pengamatan atas praktek pelaksanaan perjanjian internasional di Indonesia saat ini menunjukkan bahwa kedua model tersebut ada, namun sangat sulit untuk ditarik satu kategori umum untuk model tranformasinya, karena praktek yang ada sangat inkonsisten. Collateral effect dari kondisi ini bahwa perjanjian internasional tersebut umumnya menjadi tidak efektif karena ada keragu-raguan dari pengguna baik hakim atau aparat penegak hukum yang lain yang akan menggunakan

Wisnu Aryo Dewanto, dalam Putusan Nomor Mahkamah Konstitusi Republik Indonesia No. 33/PUU-IX/2011dalam perkara Permohonan Pengujian Undang-Undang Nomor 38 Tahun 2008 tentang Pengesahan Charter of the Association of Southeast Asian Nations (Piagam Perhimpunan Bangsa-Bangsa Asia Tenggara) terhadap Undang-Undang Dasar Negara Republik Indonesia Tahun 1945. 
substansi dari perjanjian internasional tersebut, apakah sustansinya benar-benar sudah menjadi hukum yang mengikat di Indonesia.

Berkaca dari kondisi ini maka salah satu alternatif pragmatis yang peneliti sarankan dalam penelitian ini mencantumkan perjanjian internasioanal yang diratifikasi sebagai salah satu bentuk peraturan yang diatur dalam hierarki peraturan perundang-undangan di Indonesia. Hal ini mengingat pencantuman perjanjian internasional sebagai salah satu bentuk hukum dalam hierarki PUU adakah sebagi penegasan bahwa sejak disahkan maka perjanjian internasional tersebut adalah bagian dari hukum nasional yang hidup dan harus ditaati dalam masayakat, sehingga mengakhiri perdebatan dalam pilihan transformasi tersebut masuk dalam kategori statutory ad hoc incorporation of international rules atau Automatic ad hoc incorporation of international law.

\section{c. Kewajiban Pengutamaan Perjanjian Internasional}

Negara yang telah menyatakan keterikatannya pada perjanjian internasional wajib melaksanakan isi perjanjian internasional tersebut dengan itikad baik sebagaimana diatur dalam Pasal 26 Vienna Convention 1969 dan Pasal 4 ayat (1) UU No 24 Tahun 2000. Pemenuhan kewajiban tersebut harus diposisikan secara secara aktif, artinya negara harus melakukan suatu tindakan atau langkah-langkah yang konkrit untuk melaksanakan isi perjanjian internasional. Selain itu dalam Pasal 27 Vienna Convention 1969 juga menegaskan bahwa tidak dimungkinkan menggunakan alasan pemenuhan hukum nasional untuk menangguhkan pelaksanaan dari sebuah treaty, kecuali alasan penangguhan sesuai dengan Pasal 46 Vienna Convention 1969. Mempertimbangkan pada ketentuan-ketentuan diatas dapat disimpulkan bahwa secara tidak langsung praktek hubungan internasional saat ini meletakkan pengutamanaan terhadap perjanjian internasional jika negara telah menyatakan keterikatannya pada perjanjian internasional.

Fakta ini jika dikaitkan dengan fakta yang terjadi di Indonesia bahwa penerimaan perjanjian internasional dalam hukum nasional Indonesia belum mendapat prioritas, perlu menjadi catatan penting bagi pengambil kebijakan terkait perjanjian internasional. Menjadi catatan penting, karena keberdaan konsensus pengutamaan hukum internasional atas hukum nasional ini bukan hal yang tanpa konsekuensi hukum, namun pembuktian pelanggaran terhadap kesepakatan ini juga dapat mengarah pada lahirnya pertanggungjawaban negara.

Maka membiarkan pengaturan posisi perjanjian internasional dalam sistem nasioanl yang tidak jelas bukanlah pilihan yang tepat. Pencantuman perjanjian internasioanal yang telah diratifikasi/ diaksesi oleh Pemerintah Indonesia dalam hierarki PUU di indonesia dapat menjadi solusi praktis terhadap persolaan ini. Hal ini karena pencantuman PI tersebut akan makin menguatkan posisi PI dalam hukum nasional sehingga dapat meminimalkan adanya pertentangan PI dengan Hukum Nasional. Sebagai contoh ketika Pemerintah melakukan ratifikasi PI dalam kategori kedua (PI perlu ratifikasi, perlu persetujuan DPR) ditempatkan dalam hierarki sejajar dengan UU misalnya, maka konsekuensinya pembuat regulasi dibawah UU akan menyesuaiakan peraturan yang disebutkan dengan PI tersebut, demikian pula dalam hal penerbitan UU baru juga diupayakan selaras dengan treaty yang sudah ada.

\section{d. Peluang Judicial Review oleh Mahkamah Konstitusi}

Pasal 51 ayat (3) huruf b Undang-Undang Nomor 24 Tahun 2003 tentang Mahkamah Konstitusi mengatur bahwa Mahkamah Konstitusi berwenang menguji secara formil dan materiil UU, baik itu frasa, ayat, pasal, dan/atau bagian UU yang dianggap bertentangan dengan UUD NRI Tahun 1945. ${ }^{10}$

Kaitannya dengan perjanjian internasional

10 Pasal 51 ayat (3) huruf b Undang-Undang Nomor 24 Tahun 2003 tentang Mahkamah Konstitusi (Lembaran Negara Republik Indonesia Tahun 2003 Nomor 98, Tambahan Lembaran Negara Republik Indonesia Nomor 4316) sebagaimana diubah terakhir dengan Undang-Undang Nomor 8 Tahun 2011(Lembaran Negara Republik Indonesia Tahun 2011 Nomor 70, Tambahan Lembaran Negara Republik Indonesia Nomor 5226). 
yang wujudnya saat ini di Indonesia dibungkus dalam bentuk formal UU, berarti ada peluang bagi peluang bagi Mahkamah Konstitusi untuk melakukan review terhadap substansi perjanjian internasioanal. Hal ini mengingat UU yang dimaksud dalam Pasal 57 termasuk lampirannya dan dalam UUR PI umumnya ditempatkan sebagai lampiran yang merupakan bagian tidak terpisahkan dari UU. Praktek ini telah ada di Indonesia dalam kasus Pengujian Undang-Undang Nomor 38 tahun 2008 tentang Pengesahan Charter of the Association of Southeast Asian Nations (Piagam Perhimpunan Bangsa-Bangsa Asia Tenggara) terhadap Undang-Undang Dasar Negara Republik Indonesia 1945, yang dalam putusannya yakni Putusan Mahkamah Konstitusi Nomor 33/PUUIX/2011 tentang Perkara Permohonan Pengujian Undang-undang Nomor 38 tahun 2008 tentang Pengesahan Charter of the Association of Southeast Asian Nations (Piagam Perhimpunan BangsaBangsa Asia Tenggara) terhadap Undang-undang Dasar Negara Republik Indonesia 1945 Mahkamah Konstitusi (MK) menegaskan bahwa MK memiliki kewenangan untuk melakukan pengujian atas Perjanjian Internasional yang dilampirkan dalam UU Ratifikasi, dengan asumsi bahwa perjanjian internasional tersebut merupakan dokumen yang tidak terpisahkan dengan UU Ratifikasi.

Jika didasarkan semua pembuktian yang ada, MK dalam putusannya mengabulkan permohan uji material atas substansi PI, maka berarti bahwa MK memiliki kewenangan untuk melakukan review terhadap klausula-klausula yang diatur dalam naskah perjanjian internasional yang terlampir UUR secara internal tanpa meminta persetujuan dari negara pihak yang lain. Proses pengubahan secara sepihak ini tetntu saja tidak dapat diterima dalam konteks hubungan internasional bahkan mungkin dianggap sebgai bentuk pelanggaran internasioanl yang akan mengarah pada pertanggungjawaban negara.

Maka kewenangan MK untuk melakukan review terhadap substansi perjanjian internasional adalah hal yang tidak bisa diterima, yang mungkin dilakukan hanya membatalkan keikutsertaan jika memang ada alasan yang sangat fundamental bertentangan dengan konstitusi sebagaimana difasilitasi dalam Pasal 46 Konvensi Wina 1961.

Kaitannya dengan tema penelitian ini maka, pengadosian PI di Indonesia yang dibungkus dalam bentuk formal UU, bagaimanapun akan tetap membuka peluang Mahkamah Konstitusi untuk melakukan review terhadap substansi perjanjian internasioanal, maka salah satu solusi praktis untuk mengantisipasi terjadinya hal tersebut adalah dengan pencantuman perjanjian internasioanal yang telah diratifikasi/diaksesi oleh Pemerintah Indonesia dalam bentuk mandiri di dalam hierarki PUU di Indonesia. Dimana dengan model ini maka kewenangan MK nantinya hanya terbatas pada rekomendasi pembatalan keikutsertaan dalam PIjika dirasa PI tersebut bertentangan dengan kepentingan fundamental negara, namun bukan pada review atau pembatalan satu, dua pasal perjanjian internasional.

\section{e. Kesulitan dalam Level Stocktaking dan Harmonisasi dengan Hukum Nasional}

Untuk melaksanakan ketentuan dalam Pasal 26 Konvensi Wina 1969, setidaknya ada 2 (dua) langkah penting yang harus dilakukan oleh negara adalah (1) melakukan penyelarasan substansi perjanjian internasional dengan hukum nasional; dan (2) membuat implementation legislation dari perjanjian internasional. Untuk mampu melaksanakan kedua hal tersebut maka setidaknya setiap negara dituntut untuk memiliki inventarisasi (stocktaking) terhadap perjanjian internasional yang telah diratifikasi/diaksesi dan memiliki panel pemantauan terhadap tindak lanjut yang sudah dilakukan atas perjanjian internasional tersebut. Jika kedua hal tersebut belum ada maka relatif sangat sulit bagi negara untuk mampu melaksanakan kewajiban harmonisasi dan pembuatan implementation legislation.

Praktek di Indonesia dalam pemenuhan kewajiban harmonisasi dan pembuatan implementation legislation perjanjian internasional dapat dianggap belum maksimal karena:

1) Praktek peratifikasian beberapa perjanjian internasional saat ini masih 
dianggap sebagai tindakan ceremonial belaka bukan karena kebutuhan suatu negara atas ketentuan internasional tersebut, namun lebih sebagai hadiah atas kunjungan dari Kepala Negara. Maka wajar jika tindaklanjut atas sebuat tindakan ratifikasi bukan sebuah prioritas yang harus segera dilakukan.

2) Tidak ada stocktaking terhadap keseluruhan perjanjian internasional yang telah diratifikasi dan target tindak lanjut dari ratifikasi tersebut dalam bentuk penyelarasan substansi Perjanjian Internasional dengan hukum nasional yang telah ada.

3) Tidak ada stocktaking terhadap keseluruhan perjanjian internasional yang telah diratifikasi berikut implementation legislation dari Perjanjian Internasional tersebut.

Saat ini baik Kementerian Luar Negeri RI maupun Kementerian Hukum dan HAM telah memiliki program publikasi peraturan perundangan-undangan terkait dengan perjanjian internasional. Kementerian Luar Negeri RI dan Kementerian Hukum dan HAM. Namun sangat disayangkan dalam kedua website tersebut baru mampu menunjukkan inventarisasi atas perjanjian internasional yang sudah diratifikasi namun belum mampu untuk menunjukkan tindaklanjut atas setiap ratifikasi tersebut, sehingga sangat tidak jelas apakah suatu perjanjian yang telah di ratifikasi telah diselarasakan dengan hukum nasional atau tidak dan apakah perjanjian internasional yang telah diratifikasi tersebut telah dilaksankan atau belum. Publik sama sekali tidak dapat ikut memantau dan mengawal setiap pelaksanaan dari perjanjian internasional yang ada.

Kaitannya dengan tema penelitian ini, maka pencantuman perjanjian internasional yang telah diratifikasi/diaksesi oleh Pemerintah Indonesia dalam hierarki PUU di Indonesia dapat menjadi solusi praktis terhadap persolaan ini. Hal ini karena pencantuman PI tersebut, akan merupakan media publikasi yang efektif yang menunjukkan posisi Indonesia saat ini terhadap perjanjian internasional yang bersangkutan. Tanpa harus melakukan tracing pada database perjanjian internasional publik dengan mudah dapat melihat dan ikut memantau setiap pemenuhan perjanjian internasional yang telah diikuti oleh Pemerintah Indonesia. Selain itu, model pencantuman perjanjian internasional secara mandiri akan lebih mudah mencari penyelesaian dalam hal terjadi inkonsistensi antara substansi Perjanjian Internasional dengan hukum nasional, sementara proses harmonisasi belum dilakukan. Hal ini dikarenakan pencantuman secara mandiri dalam hierarki akan berkonsekuensi penegasan level perjanjian internasional dalam hukum nasional.

\section{f. Trend Akselerasi Peningkatan Keikut- sertaan dalam Perjanjian Internasional}

Keikutsertaan Indonesia terhadap perjanjian internasional, untuk tiap tahunnya jumlah keikutsertaan Indonesia terus meningkat. Basis Data Perjanjian Internasional yang dipublikasikan Kementerian Luar Negeri RI tercatat bahwa untuk tahun 2012 Indonesia menyatakan keikutsertaannya terhadap 138 perjanjian internasional. Jumlah tersebut meningkat pada tahun 2013, dimana Indonesia tercatat ikut serta dalam 165 perjanjian internasional. ${ }^{11}$ Khususuntukperjanjianinternasional yang multilateral dalam kurun waktu 2000-2010, Indonesia tercatat menyatakan keikutsertaannya terhadap 98 perjanjian multilateral ${ }^{12}$ Sementara untuk perjanjian internasional yang bilateral, data dalam Treaty Room Kementerian Luar Negeri RI menunjukkan bahwa saat ini Indonesia tercatat telah memiliki perjanjian bilateral dengan 135 Negara. ${ }^{13}$

11 Kementrian Luar Negeri Republik Indonesia, "Basis Data Perjanjian Internasional (Treaty Database)", http://treaty.kemlu.go.id/ index.php/ treaty/index, diakses 7 Januari 2014.

12 Bentuk ratifikasi 98 Perjanjian Multilateral tersebut, 19 dalam bentuk Undang-Undang, 51 dalam bentuk Keppres dan 28 dalam bentuk Perpres. Lihat juga Direktorat Jenderal Peraturan Perundang-Undangan, "Database Peraturan", http://ditjenpp.kemenkumham.go.id/databaseperaturan.html, diakses 7 Januari 2014.

13 Daftar Perjanjian Bilateral, Kementerian Luar Negeri Republik Indonesia Tahun 2014. 
Catatan lain, dalam Treaty Participation di United Nations Treaty Collection (UNTC) tercatat hingga saat ini Indonesia berpartisipasi dalam 262 perjanjian internasional. ${ }^{14}$

Peningkatan keikutsertaan terhadap perjanjian internasional, tentu saja menuntut kesiapan negara untuk mampu melaksanakan berbagai kewajiban hukum yang lahir dari perjanjian internasional tersebut. Maka sebuah terobosan untuk membuat pemenuhan perjanjian internasioanal agar lebih effektif harus dilakukan. Salah satu rekomendasi peneliti adalah dengan pencantuman perjanjian internasioanal yang telah diratifikasi/diaksesi oleh Pemerintah Indonesia dalam hierarki PUU di Indonesia. Dimana pemuatan secara mandiri dalam hierarki PUU akan lebih memberikan jaminan kepastian hukum untuk dilaksanakan.

\section{g. Kegagalan Pemenuhan Perjanjian Internasional Tidak Otomatis Melahirkan Pertanggungjaban Negara}

Mengacu pada Draft ILC on Responsibiliy of States For Internatinally Wrongful Acts (DRS), maka kegagalan pemenuhan kewajiban dalam perjanjian internasional seharusnya dapat dianggap sebagai pelanggaran kewajiban internasional. Namun, praktek yang terjadi dalam konstelasi hubungan internasional bahwa tidak serta merta kegagalan suatu negara dalam memenuhi perjanjian internasional akan membawa negara tersebut pada pertanggungajawaban negara. Hal ini karena dalam praktik, yang diacu adalah kondisi riil, selama tidak ada negara pihak yang merasa dirugikan dengan tidak dilaksanakan nya perjanjian internasional oleh suatu negara tertentu dan mengajukan tuntutan pertanggungjawaban negara maka dapat dikatakan bahwa negara tersebut masih dalam koridor melaksanakan perjanjian internasional dengan itikad baik. Konsep ini secara tidak langsung dapat ditafsirkan mengakomodir tindakan pemenuhan kewajiban pelaksanaan perjanjian internasional dengan itikad baik secara pasif yang memberikan toleransi kepada negara yang belum mampu melaksanakan kewajiban yang terlahir dari perjanjian internasional sepanjang tidak ada negara yang dirugikan dan melakukan tuntutan pertanggungjawaban negara terhadap negara pihak yang bersangkutan.

Untuk konteks Indonesia, paktik di Indonesia hingga saat ini (2014) tercatat bahwa belum pernah terjadi dalam sejarah Indonesia, Indonesia diajukan ke Mahkamah Internasional untuk suatu kasus pelanggaran internasional yang lahir dari perjanjian internasional. ${ }^{15}$ Namun demikian hal ini bukan berarti Indonesia patut merasa nyaman berada dalam situasi belum secara maksimal melakukan pemenuhuan kewajiban perjanjian internasioal. Hal ini mengingat bahwa setiap tindakan yang tidak sesuai dengan kesepakatan atau dalam hal ini perjanjian internasional akan tetap memberikan stigma buruk pada performa Indonesia di level internasional. Oleh karena itu pilihan tidak menjadikan pemenuhan perjanjian internasional sebagai prioritas karena kemungkinan sangat kecil dibawa ke ranah pertanggungjawaban negara, bukanlah pilihan yang bijak untuk terus dilanjutkan. Salah satu rekomendasi peneliti adalah dengan pencantuman perjanjian internasioanal yang telah diratifikasi/diaksesi oleh Pemerintah Indonesia dalam hierarki PUU di Indonesia. Dimana pemuatan secara mandiri dalam hierarki PUU akan lebih memberikan jaminan kepastian hukum untuk dilaksanakan.

\section{Tantangan Penempatan Perjanjian Internasional yang Mengikat Indonesia dalam Hierarki Peraturan Perundang- Undangan}

Setiap perubahan stuktur pasti akan membawa implikasi positif dan negatif, semua

14 UN, "Treaty Participation di United Nations Trety Collection", https://treaties.un.org/Pages/TreatyParticipant Search.aspx?tab=UN, diakses 7 Januari 2014.

15 Berdasarkan Contentious Cases yang diperoleh dari International Court of Justice, menunjukkan Indonesia tercatat pernah satu kali beracara di Mahkamah Internasional untuk satu kasus "Sovereignty over Pulau Ligitan and Pulau Sipadan (Indonesia/Malaysia)" bukan untuk kasus pelanggaran internasional yang lahir dari perjanjian internasional. Lihat ICJ, "Contentious cases di International Court of Justice”, http://www. icj-cij.org/, diakses 12 Mei 2014. 
implikasi tersebut perlu dikaji secara mendalam dan dipertimbangkan dengan baik. Perimbangan ini khususnya terhadap implikasi negatif dari suatu tindakan, perlu pengkajian yang mendalam apakah implikasi negatif (tantangan) yang muncul nanti masih mampu diatasi atau tidak. Hak ini senada dengan prinsip umum dalam hukum internasional yaitu the precautionary principle. Prinsip ini merekomendasikan eksekusi pilihan jika semua tantangan yang muncul yakin akan teratasi dengan baik. Tantangan ini bukan saja tantangan yang sifatnya nyata saat ini namun juga prediksi tantangan dimasa depan. Kaitannya dengan penelitian ini, bahwa untuk mengkaji peluang atau pilihan kemungkinan untuk menempatkan perjanjian internasioanl yang telah diratifikasi/diaksesi oleh Pemerintah Indonesia dalam bentuk mandiri di dalam hierarki peraturan perundang-undangan Indonesia, selain dilakukan analisis urgensi dan keuntungan perlu dilakukan analisis atas tantangan yang mungkin muncul dengan kebijakan tersebut, sebagai berikut:

\section{a. Negara Harus Lebih Konsisten}

Sistem hierarki menimbulkan dampak kepastian hukum yang absolut, maka jika perjanjian internasional dimasukkan ke dalam hierarki juga akan berdampak sama. Perjanjian internasional tersebut akan sangat berpengaruh dalam hukum nasional suatu negara. Mekanisme ini akan memberikan kekuatan yang sangat besar kepada perjanjian internasional untuk "menyetir" bahkan menentukan sikap dari suatu negara. ${ }^{16}$ Peran strategis perjanjian internasional jika masuk dalam hierarkhi tersebut menuntut negara untuk ektra hati-hati dalam keputusannya untuk mengikatkan diri dalam suatu perjanjian internasional. Negara harus jeli melihat perkembangan hukum dan politik di sekitarnya untuk meminimalisir kemungkinan "political interest" yang terselubung dari pihak lain.

Mekanisme ini juga menuntut negara untuk konsisten dalam melaksanakan berbagai kewajiban hukum yang muncul sebagai konsekuensi keterikatan atas perjanjian internasional sebagaimana diatur dalam Pasal 26 dan 27 Konvensi Wina 1969. Jika Indonesia akan melaksanakan mekanisme ini maka harus dipastikan terlebih dahulu kesiapan setiap elemen untuk mampu melaksanakan konsekuensi dari sebuah tindakan pengikatan perjanjian internasional. Kesiapan ini berati menuntut koordinasi ekstra antar kementrian dalam keputusan untuk pengikatan diri. Meskipun sebenarnya mekanisme koordinasi antar kementrian ini sudah diamanatkan secara tegas dalam UU No. 24 Tahun 2000 namun dalam prakteknya banyak keterikatan Indonesia dalam berbagai perjanjian internasional tidak lahir dari proses koordinasi kementrian yang baik yang disertai denagn analisis keunggulan dan tantangan peratifikasian serta tindaklanjut paska peratifikasian. Bahkan beberapa perjanjian internasional lahir bukan karena kebutuhan negara atas perjanjian internasional namun lebih sebagai hadiah persahabatan antarnegara atau semata-mata hanya untuk menaikkan citra negara dihadapan internasional.

Selain itu untuk menjamin konsistensi Pemerintah Indonesia untuk melakukan pemenuhan perjanjian internasional juga diperlukan inventarisasi dan pemantauan pelaksanaan dari perjanjian internasional yang lebih memberi ruang kepada publik untuk juga melakukan pengawasan terhadap setiap tahap pemenuhan perjanjian internasional. Hal ini penting mengingat mekanisme harmonisasi (penyelarasan perjanjian internasional dengan hukum internasional) dan pembuatan peraturan pelaksana (implementation legislation) sebagai yang amanat dalam perjanjian internasional, yang saat ini dibebankan kepada 2 (dua) lembaga utama Kementerian Luar Negeri dan Kementerian Hukum dan HAM kurang efektif. Keterbatasan SDM dan keterbatasan teknologi yang digunakan selalu dijadikan justifikasi atas kegagalan dalam melaksanakan kewajiban harmonisasi dan pembuatan peraturan pelaksana perjanjian internasional. 
b. Negara Wajib Mengalihbahasakan Setiap Perjanjian Internasional

Sebagaimana diamati dalam praktek penerapan perjanjian dalam hukum nasional suatu negara, praktek negara-negara yang telah mengimplementasikan pencantuman perjanjian internasional yang telah diikuti oleh negara tersebut dalam hierarki peraturan perundang-undangannya adalah negara-negara yang berbahasa Inggris, yang secara umum masyarakatnya mampu memahami dengan baik setiap redaksi perjanjian internasional yang umumnya juga dibuat dalam bahasa Inggris.

Maka tantangan bagi negara-negara yang tidak berbahasa Inggris (yang sebagian besar warganya tidak berbahasa Inggris), jika akan menerapkan model pencantuman perjanjian internasioanl dalam hierarki peraturan perundangundangan maka negara harus menjamin adanya mekanisme pengalihan bahasa terhadap setiap peerjanjian internasional yang dimaksud dalam bahasa yang dimengerti oleh seluruh warga negaranya. Dalam konteks Indonesia jika Indonesia memang akan menerapkan mekanisme ini maka harusnya Pemerintah Indonesia mampu memfasilitasi pengalihan bahasa dalam perjanjian internasional ke dalam Bahasa Indonesia.

Saat ini sebenarnya dalam Pasal 31 UndangUndang Republik Indonesia Nomor 24 Tahun 2009 tentang Bendera, Bahasa, dan Lambang Negara, serta Lagu Kebangsaan telah dimuat mandat bahwa setiap perjanjian internasional yang dibuat oleh Pemerintah Indonesia Wajib dibuat salinannya dalam Bahasa Indonesia. ${ }^{17}$ Namun dalam prakteknya paska pengundangan UU tersebut belum ada konsistensi semua perjanjian internasional yang diratifikasi/ diaksesi oleh pemerintah yang dilampirkan dalam instrumen ratifikasi dibuat salinannya dalam bahasa Indonesia.

Fakta ini memberikan peringatan penting, jika Indonesia akan mengikuti model pencantuman
PI dalam hirakhi PUU maka persolaan alih bahasa ini harus dikerjakan lebih baik dari mekanisme yang ada sekarang bahkan jika perlu harus dibentuk lembaga khusus dibawah satu kementerian yang ada untuk melakukan fungsi tersebut. Hal ini mengingat setiap bentuk pengundangan suatu peraturan akan membawa pada fiksi hukum setiap orang tanpa terkecuali dianggap mengetahui semua hukum/undang-undang yang berlaku dan apabila melanggarnya, akan dituntut dan dihukum berdasarkan undang-undang/hukum yang berlaku tersebut. Kondisi ini didasarkan pada teori fictie yang menyatakan bahwa begitu suatu norma hukum ditetapkan, maka pada saat itu setiap orang dianggap tahu hukum/undang-undang (een ieder wordt geacht de wet/het recht te kennen). Ketidaktahuan seseorang akan hukum tidak dapat dijadikan alasan pemaaf atau membebaskan orang itu dari tuntutan hukum (ignorantia iuris neminem excusat/ignorance of the law excuses no man).

\section{c. Negara Wajib Membuat Kualifikasi Perjanjian Internasional}

Melihat konsekuensi dalam sebuah hierarki akan berlaku hub sub ordinasi, maka jika Indonesia akan mengikuti model pencantuman PI dalam hirakhi PUU maka persolaan kualifikasi perjanjian internasional yang mana yang akan dimasukkan dalam hierarki PUU (apakah semua kulaifikasi perjanjian internasional atau hanya perjanjian internasional dalam kualifikasi tertentu) dan dalam level mana pencantumannya harus mendapat perhatian yang serius dan untuk menjamin konsistensinya harus ditetapkan dalam satu norma hukum. Sebagaimana telah diuraikan bahwa saat ini perjanjian internasioanl di Indonesia dapat dikualifikasikan dalam 3 (tiga) kategori sebagai berikut:

1) Perjanjian Internasional yang akan dapat langsung berlaku tanpa mempersyaratkan adanya proses

Pasal 31 Undang-Undang Nomor 24 Tahun 2009 tentang Bendera, Bahasa, dan Lambang Negara, Serta Lagu Kebangsaan bahwa: (1) Bahasa Indonesia wajib digunakan dalam nota kesepahaman atau perjanjian yang melibatkan lembaganegara, instansi pemerintah Republik Indonesia, lembaga swasta Indonesia atau perseorangan warga negara Indonesia. (2) Nota kesepahaman atau perjanjian sebagaimana dimaksud pada ayat (1) yang melibatkan pihak asing ditulis juga dalam bahasa nasional pihak asing tersebut dan/atau bahasa Inggris. (Lembaran Negara Republik Indonesia Tahun 2009 Nomor 109, Tambahan Lembaran Negara Republik Indonesia Nomor 5035). 
2) Perjanjian internasional yang memerlukan transformasi dalam hukum nasional (legislative ad hoc incorporation) dan memerlukan persetujuan Dewan Perwakilan Rakyat dalam proses tranformasinya.

3) Perjanjian internasional yang memerlukan transformasi dalam hukum nasional (legislative ad hoc incorporation) namun tidak membutuhkan persetujuan Dewan Perwakilan Rakyat dalam proses tranformasinya. Masing-masing kategori ini belum ada kualifikasi yang spesifik sehingga parktek inkonsisten dalam pengkategorian tersebut masih terjadi. Hal ini jika tidak diatasi dengan baik justru berpotensi besar menimbulkan kekacauan hukum ketika perjanjian internasional dimasukkan dalam sistem hierarki PUU di Indonesia.

\section{d. Negara Harus Merevisi Undang-Undang Terkait Perjanjian Internasional dan Hieraki Peraturan Perundang-Undangan}

Pencantuman perjanjian internasioanl dalam bentuk mandiri dalam hirakhi Peraturan Perundangundangan di Indonesia tentu akan memberikan perubahan yang masif dalam pengaturan tentang perjanjian internasioanal yang diatur dalam UU No. 24 Tahun 2000 tentang Perjanjian Internasional (UU PI) khususnya terkait dengan persolan bentuk dan mekanisme ratifikasi. Demikian pula dengan stuktur hierarki peraturan perundang-undangan di Indonesia yang selama ini diatur dalam UndangUndang Nomor 12 Tahun 2011 tentang Pembentukan Peraturan Perundang-Undangan (UU PPP) juga harus disesuaikan dengan mengakomodasi perjanjian internasional di dalamnya. Sementara untuk ketentuan dalam Pasal 11 UUD NRI Tahun 1945 tidak perlu mengalami perubahan karena dari awal konsistusi tidak pernah mengharuskan suatu perjanjian internasional yang sudah diratifikasi/ diaksesi oleh Pemerintah Indonesia harus diwadahi dalam baju undang-undang atau peraturan presiden.

\section{Kesimpulan}

Urgensi penempatan perjanjian internasional yang mengikat Indonesia dalam hierarki peraturan perundang-undangan meliputi: (1) adanya pergeseran paradigma pemaknaan sumber hukum yang lebih sempit sebatas apa yang tertera dalam hierarhi peraturan perundang-undangan; (2) ketidakjelasan pilihan model transformasi perjanjian internasional yang diterapkan di Indonesia; (3) kewajiban pengutamaan perjanjian internasional dalam hal suatu negara telah menyatakan keterikatannya; (4) peluang judicial review atas materi perjanjian internasional oleh Mahkamah Konstitusi; (5) solusi atas kesulitan dalam level stocktaking dan harmonisasi dengan hukum nasional; (6) adanya tren akselerasi peningkatan keikutsertaan dalam perjanjian internasional; dan (7) solusi atas asumsi bahwa kegagalan pemenuhan perjanjian internasional tidak otomatis melahirkan pertanggungjawaban negara.

Adapun tantangan penempatan perjanjian internasional yang mengikat Indonesia dalam hierarki peraturan perundang-undangan antara lain bahwa: (1) negara harus lebih konsisten; (2) negara wajib mengalihbahasakan setiap Perjanjian Internasional; (3) negara wajib membuat kualifikasi perjanjian internasional; dan (4) negara harus merevisi undang-undang terkait perjanjian internasional dan hieraki peraturan perundangundangan.

Sementara berdasarkan hasil penelitian ini disarankan bahwa penempatan perjanjian internasional yang telah diratifikasi/diaksesi oleh Pemerintah Indonesia dalam hieraki peraturan perundang-undangan Indonesia sebenarnya dapat dijadikan solusi pragmatis yang dapat diambil oleh Pemerintah Indonesia untuk mengatasi ketidakjelasan posisi perjanjian internasional yang berimplikasi pada terhambatnya upaya pemenuhan perjanjian internasional. Lebih lanjut, bahwa pilihan penempatan perjanjian internasional 
yang telah diratifikasi/diaksesi oleh Pemerintah Indonesia dalam hieraki peraturan perundangundangan Indonesia meskipun secara jelas akan menyelesaikan berbagai persoalan dan membawa beberapa keuntungan, namun disisi lain juga menuntut banyak persiapan secara teknis dan kelembagaan untuk menuju pada model tersebut. Selain itu, sebaiknya dilakukan semua persiapan, hingga Indonesia akan benar-benar siap menerima implikasi dari pemberlakuan model penempatan perjanjian internasional yang telah diratifikasi/ diaksesi oleh Pemerintah Indonesia dalam hierarki Peraturan Perundang-undangan Indonesia, sebelum akhirnya benar-benar beralih pada pilihan model ini.

\section{DAFTAR PUSTAKA}

\section{A. Buku}

Agusman, Damos Dumoli, 2010, Hukum Perjanjian Internasional-Kajian Teori dan Praktik Indonesia, Rifika Aditama, Bandung.

Dixon, Martin, 2007, Textbook on International Law, Oxford University Press, New York.

Fitzmaurice, Gerald, 1957, The General Principles of International Law Considered from the Standpoint of the Rule of Law, Martinus Nijhoff, Leiden/Boston.

Joeniarto, 1983, Selayang Pandang tentang SumberSumber Hukum Tata Negara di Indonesia, Liberty, Yogyakarta.

Kusumaatmadja, Mochtar, 1978, Pengantar Hukum Internasional, Penerbit Bina Cipta, Bandung.

Leigh, Monroe, 2005, National Treaty and Law Practice, Martinus Nijhoff, Leiden/Boston.

Pratomo, Eddy 2011, Hukum Perjanjian Internasional: Pengertian, Status Hukum dan Ratifikasi, Alumni, Bandung.

Starke, J.G., 2010, Pengantar Hukum Internasional, Edisi Kesepuluh, Sinar Grafika, Jakarta,

\section{B. Jurnal}

Ariandno, Melda Kamil, "Kedudukan Hukum Internasional dalam Sistem Hukum Nasional", Indonesian Journal of Internasional Law, Vol. 5, No. 3, April 2008.

Siahaan, Lintong O., "Peran Hakim dalam Pembaharuan Hukum di Indonesia", Jurnal Hukum dan Pembangunan, Vol. 36, No. 1, Januari 2006.

\section{B. Makalah}

R., Ibrahim, "Status Hukum Internasional dan Perjanjian Internasional di dalam Hukum Nasional (Permasalah Teoritik dan Praktek)", Makalah, Lokakarya Evalusi UndangUndang No. 24 Tahun 2000 tentang Perjanjian Internasional, Surabaya, 18-19 Oktober 2008.

Latifulhayat, Atip, "Perjanjian Internasional dalam Konteks Relasi dan Interaksi anatara Hukum Internasional dan Hukum Nasional", Makalah, FGD Hukum Perjanjian Internasional kerjasama Fakultas Hukum Unair dengan Kementria Luar Negeri Republik Indonesia, Surabaya, 25 November 2011.

\section{Internet}

Direktorat Jenderal Peraturan PerundangUndangan, "Database Peraturan", http:// ditjenpp.kemenkumham.go.id /databaseperaturan.html, diakses 7 Januari 2014.

ICJ, "Contentious cases di International Court of Justice", http://www.icj-cij.org/, diakses 12 Mei 2014.

Kementrian Luar Negeri Republik Indonesia, "Basis Data Perjanjian Internasional (Treaty Database), http://treaty.kemlu.go.id/ index. php/treaty/index, diakses 7 Januari 2014.

UN, "Treaty Participation di United Nations Trety Collection", https://treaties.un.org/ Pages/ TreatyParticipant Search.aspx?tab $=U N$, diakses 7 Januari 2014. 


\section{Peraturan Perundang-undangan}

Konstitusi Korea Selatan 1987.

Undang-Undang Dasar Negara Republik Indonesia Tahun 1945.

Undang-Undang Republik Indonesia Nomor 24 Tahun 2000 tentang Perjanjian Internasional (Lembaran Negara Republik Indonesia Tahun 2000 Nomor 185, Tambahan Lembaran Negara Republik Indonesia Nomor 4012).

Undang-Undang Nomor 24 Tahun 2003 tentang

Mahkamah Konstitusi (Lembaran Negara Republik Indonesia Tahun 2003 Nomor 98, Tambahan Lembaran Negara Republik Indonesia Nomor 4316).

Undang-Undang Nomor 8 Tahun 2011 tentang Perubahan atas Undang-Undang Nomor 24 Tahun 2003 tentang Mahkamah Konstitusi
(Lembaran Negara Republik Indonesia Tahun 2011 Nomor 70, Tambahan Lembaran Negara Republik Indonesia Nomor 5226).

Undang-Undang Republik Indonesia Nomor 12 Tahun 2011 tentang Pembentukan Peraturan Perundang-undangan (Lembaran Negara Republik Indonesia Tahun 2011 Nomor 82, Tambahan Lembaran Negara Republik Indonesia Nomor 5234).

United States Constitution.

Case-Zablocki Act of 1972, 1 USC 112B.

Vienna Convention on the Law of Treaties 1969.

Vienna Convention on the Law of Treaties between States and International Organizations or between International Organizations, 1986.

Daftar Perjanjian Bilateral, Kementerian Luar Negeri Republik Indonesia Tahun 2014. 